\title{
ホイップドクリームの物性に及ぼす気泡の大きさと脂肪球凝集の影響
}

\author{
井原啓一 ${ }^{\S}$, 丸屋美樹*，尾崎裕司 ${ }^{* *}$, 嶋田康伸***, 浅野祐三，岩附慧二 \\ 森永乳業株式会社食品基盤研究所 \\ *森永乳業株式会社分析センター \\ ** 森永乳業株式会社応用技術センター \\ *** 森永乳業株式会社食品総合研究所
}

\section{Influences of Bubble Size and Fat Globules Aggregation on the Physical Characteristics of Whipped Cream}

(Studies on Factors Influencing Physical Characteristics of Whipped Cream Part II)

\author{
Keiichi Ihara ${ }^{\S}$, Miki Maruya*, Yuji Ozaki**, Yasunobu Shimada***, \\ Yuzoh Asano and Keiji Iwatsuki \\ Food Science \& Technology Institute, Morinaga Milk Industry Co., Ltd., \\ 5-1-83 Higashihara, Zama, Kanagawa 228-8583 \\ * Analytical Research Center, Morinaga Milk Industry Co., Ltd., \\ 5-1-83 Higashihara, Zama, Kanagawa 228-8583 \\ ** Product Evaluation Center, Morinaga Milk Industry Co., Ltd., \\ 5-1-83 Higashihara, Zama, Kanagawa 228-8583 \\ *** Food Research \& Development Institute, Morinaga Milk Industry Co., Ltd., \\ 5-1-83 Higashihara, Zama, Kanagawa 228-8583
}

\begin{abstract}
The size of bubbles and degree of fat globule aggregation in cream have been reported to influence the shape retention ability of whipped cream. Shape retention ability also changes when whipped cream is stored. In order to investigate bubble size and fat globule aggregation, fresh cream with $45 \%$ (w/w) fat was whipped to stiffness at different speeds (140, 180 or $200 \mathrm{rpm})$. Differences in resistivity against deformation during storage were found in whipped cream prepared at different whipping speeds. It appears that the degree of fat globule aggregatation and overrun of the whipped cream influenced resistivity against deformation. Furthermore, higher correlation was found between the overrun and the continuous phase viscosity of the sample whipped at $140 \mathrm{rpm}$, and between the average bubble size and the degree of fat globules aggregation of the sample prepared at $200 \mathrm{rpm}$. The present results suggest that the degree of fat globule aggregation in the continuous phase influence the shape retention ability of cream whipped at 140 $\mathrm{rpm}$, and that the presence of aggregates of fat globules on the surface of bubbles influence the shape retention ability of the cream whipped at $200 \mathrm{rpm}$ (Received Jun. 8, 2006 ; Accepted Jan. 18, 2007)
\end{abstract}

Keywords : whip, cream, physical characteristics, fat globule aggregation, foam キーワード：ホイップ, クリーム, 物性, 脂肪球凝集, 気泡

ホイップしたホイップクリーム（ホイップドクリーム） は経時的に保形性が低下していく，その原因としてはホ イップドクリームからの液状部分の流下，オストワルド熟 成による気泡の成長, 気泡の崩壊などが考えられている11.

\footnotetext{
†ホイップドクリーム物性に影響を及ぼす因子に関する研究（第 2 報）（前報，文献 4)）

$*$ 干228-8583 神奈川県座間市東原 5-1-83)

** $\boldsymbol{0} 228-8583$ 神奈川県座間市東原 5-1-83)

*** 个228-8583 神奈川県座間市東原 5-1-83)

§ 个228-8583 神奈川県座間市東原 5-1-83)

連絡先 (Corresponding author), k_ihara@morinagamilk.co.jp
}

一方，気泡の周りには脂肪球が集まっており ${ }^{2) 3}$ それらの 脂肪球の凝集体は気泡表面の安定性, 気泡間のネットワー クの形成を行っている3 ${ }^{3)}$ と報告されており，ホイップドク リームの保形性を維持するのに役立っている. 従って, 脂 肪球凝集体の経時変化も保形性の変化に大きな影響を及ぼ しているあのと思われる。しかし，ホイップドクリームの 経時的な保形性变化と気泡, 脂肪球凝集状態の变化との関 係について解析した報告はほとんどないのが現状である.

また，経時的な保形性变化はホイップ速度によって異な り， 前報 ${ }^{4)}$ では，高速ホイップ品は保形性および気泡径の 
変化が大きく, 低速ホイップ品は保形性および気泡径の変 化が小さいことを示した。本研究ではホイップ速度を変え てホイップしたクリームの経時的な力学物性变化について 測定し, 脂肪球凝集体, 気泡の状態变化が保形性に与える 影響について検討したので報告する。

\section{実 験 方 法}

\section{1. 試 料}

本試験で用いるホイップクリームは, 森永乳業 (株) 製の 脂肪率 45\%, 脂肪球の体積基準によるメディアン径（50\% 径）が $2.2 \mu \mathrm{m}$ から $2.3 \mu \mathrm{m}$ の範囲のフレッシュクリームを 用いた。

\section{2. 脂肪球の粒度分布および平均粒子径測定法}

(株)堀場製作所製レーザー回折式粒度分布計 LA-500を 用いた。逆浸透膜処理した後にイオン交換処理された $25^{\circ} \mathrm{C}$ の純水 (電気伝導度 $1 \mathrm{~ms} / \mathrm{cm}$ 以下) に希釈したクリームを 測定試料にした。

\section{3. ホイップ方法}

ホイップにはバッチ式ホイッパーである愛工舎のケン ウッド社製ミキサー（ケンミックスメジャー，攪拌子のワ イヤー 12 本）を用いた。 ホイップには $1 \mathrm{~kg}$ のリームを 用い, クリームへのショ糖の添加はクリーム重量に対して $8 \%$ とした。 ホイップ開始のクリーム温度は $7^{\circ} \mathrm{C}$ と, ホ イップ後にはホイップドクリームの温度はおおよそ $11^{\circ} \mathrm{C}$ から $12^{\circ} \mathrm{C}$ の範囲となった。ペネトロ針入度試験機5) で測定 したホイップドクリームのペネトロ針入度が $135 \pm 2,200$ 土2または $215 \pm 2$ となったところをホイップの終点とし た. 本研究ではペネトロ針入度測定において菊地 ${ }^{6)}$ が用い た方法を採用し, 質量 $12 \mathrm{~g}$, 先端角 $40^{\circ}, コ ー ン$ 最上部の直 径 $24 \mathrm{~mm}$, コーン下端から最上部までの長さが $33 \mathrm{~mm}$ の 円錐状コーンを用い，コーンが試料に針入してから 5 秒後 の值を用いた。

ホイップ速度は攪拌子の回転数として $140 \mathrm{rpm}, 180 \mathrm{rpm}$, $200 \mathrm{rpm}$ の 3 水準であった.

\section{4. ホイップドクリーム中の脂肪球凝集率の推定法}

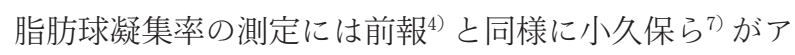
イスクリームで使用した方法を用いた。すなわち，ホイッ プ操作前のクリームにおける体積頻度による $90 \%$ 径以下 の脂肪球を「未凝集」の脂肪球と定義し, ホイップ操作後 によ゙のくらいの割合が $90 \%$ 径以上に「凝集」しているか推 測したものである。この凝集率測定法により, 脂肪球数個 の小さな凝集体から多数個の脂肪球が凝集して大きくなっ た凝集体までの合計量を求めることができる.

\section{5. 平均気泡径測定法}

ホイップ済み試料を液体窒素にて凍結させ, 液体窒素中 にて割断した。 その試料を液体窒素で冷却していたステー ジに載せ，走査型電子顕微鏡（トプコン（株）製 SM-200） を用いて高真空 $\left(10^{-3} \mathrm{~Pa}\right)$ にて蒸着処理無しで観察した。
加速電圧は $5 \mathrm{kV}$, スポットサイズとしては No. 5 の条件を 用いた。 そして, その画像の気泡径を測定し平均径を求め た. すなわち, 画像中 $0.3 \sim 1.8 \mathrm{~mm}^{2}$ の領域の気泡（気泡個 数として 150 200 個) の円相当直径を求め, 野田ら ${ }^{8)}$ が用 いた下式の平均体積径を求め平均径とした。

$$
\begin{aligned}
& \mathrm{D}_{\mathrm{v}}=\left(\sum\left(\mathrm{nD}_{\mathrm{a}}{ }^{3}\right) / \sum \mathrm{n}\right)^{1 / 3} \\
& \mathrm{D}_{\mathrm{v}} \text { : 平均体積気泡径 }[\mu \mathrm{m}] \\
& \mathrm{D}_{\mathrm{a}} \text { : 個々の気泡径 }[\mu \mathrm{m}] \\
& \mathrm{n} \text { : 測定個数 }[-]
\end{aligned}
$$

\section{6. ホイップドクリーム連続相の粘度測定}

前報 ${ }^{4)}$ と同様に Noda $ら^{2)}$ の方法を用いた. すなわち，ホ イップドクリームをアスピレーターにて脱気し，それを コーンプレート型粘度計 (Haake 社製 Roto Visco 1) を用 いて粘度測定をした。測定には $35 \mathrm{~mm}$ 径, 角度 1 \# 66 の コーンを用い, 温度 $5{ }^{\circ} \mathrm{C}$, せん断速度 $300 \mathrm{~s}^{-1}$ の条件を用い た. 以上の方法によりホイップドクリームの気泡以外の部 分である「連続相」の粘度を測定した.

\section{7. ホイップドクリームの変形抵抗性測定}

粘弾性測定装置（ティー・エー・インスッルメンツ社製 ARES）を用いた。 測定セルには $25 \mathrm{~mm}$ 径の平行円板を用 い，試料をその 2 枚の平板間に充填し， $1.8 \sim 2.0 \mathrm{~mm}$ 程度

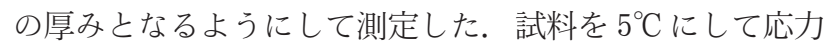
掃引モード（200 Pa/2 分間の変化率）でひずみを測定し， 試料のひずみが 0.1 となった時点での応力を本研究では 「变形抵抗性」と定義した。 ここで, 变形抵抗性が大きいほ ど保形性のあるホイップドクリームであると考えられる.

\section{8. ホイップドクリームの保形性の測定}

絞り袋を用いてホイップドクリームを黒色の紙の上に $15 \mathrm{~g}$ だけ絞り出し, Fig. 1a のような花の形状にして, 直ち に上部より撮影した。 その写真よりホイップドクリームの 底面積を求めた。この值を本研究におけるホイップドク リームの特性值である形状安定性すなわち「保形性」の指 標值とした，花を描いたときの底面積が小さいほど，重力 に対して形を保つ力すなわち保形性が大きいといえる (Fig. 1 (a)). 逆に保形性が小さいと描いた直後に花がつ ぶれて, 底面積が大きくなる（Fig. 1（a)）。前項の变形抵 抗性がいわゆるホイップドクリームの「保形性」と相関性 があり，有効な測定值であるかどうかの検証に用いた。

\section{実験結果および考察}

\section{1. ホイップドクリームの保形性と変形抵抗性との関係}

変形抵抗性が保形性を代表しえるパラメータであるかど うかを検証するため，それらの関係を Fig. 1 （b）に示し た. Fig. 1（a）の写真に示したとおり，ホイップ直後のホ イップドクリームを絞り袋に入れて花を描くと, 自重での ひずみが小さいため底面積が小さく, 保形性が良好である ことが分かった。一方, 冷蔵 $\left(5^{\circ} \mathrm{C}\right)$ 保存したホイップドク 
(a)

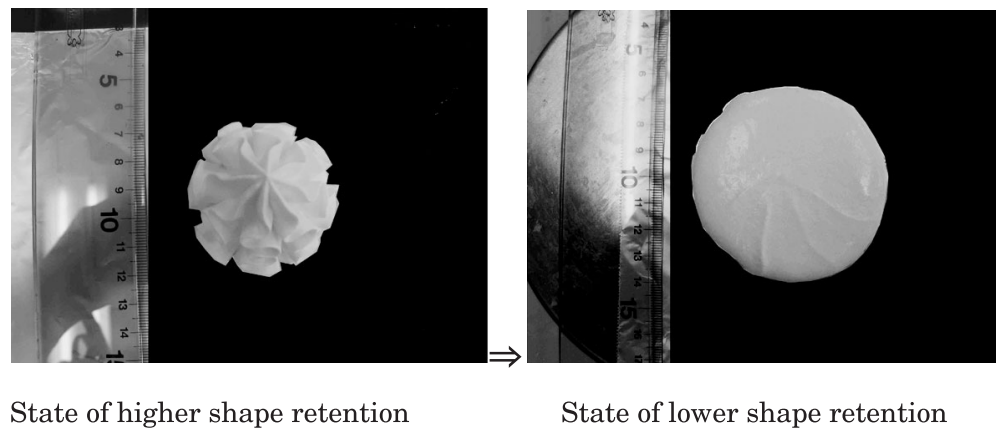

(b)

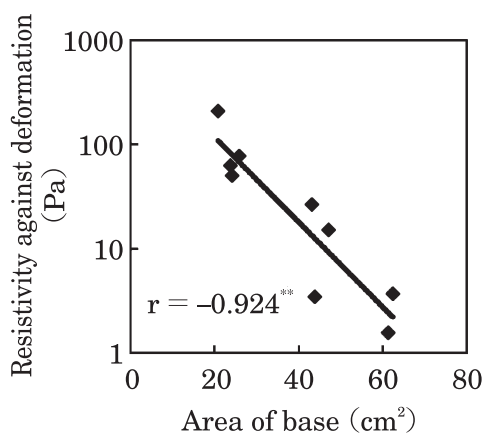

Fig. 1 Correlation between resistivity against deformation and base area of whipped cream

(a) Observation of shape retention of the whipped cream.

(b) Correlation between resistivity against deformation and base area.

** : Significant at $p<0.01$.

(a)

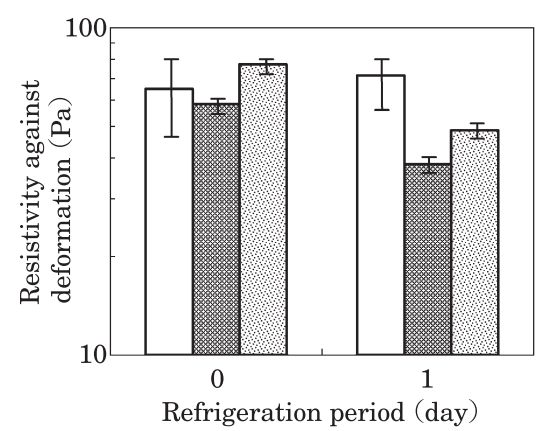

(b)

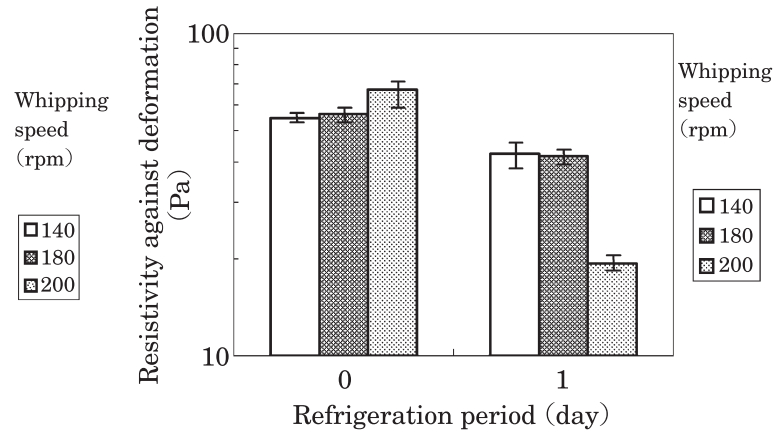

Fig. 2 Resistivity against deformation of whipped cream
(a) Test at penetrometer value of 215
(b) Test at penetrometer value of 200 .
$\mathrm{n}=3$.

リームでは花が自重によってひずみ, 底面積が増加し, 保 形性が低下していることが分かった。様々な保形性を持っ ホイップドクリームについて検討するため, Fig. 1（b）は ホイップ終了時の硬さを変えて（ペネトロ針入度が 135 , 200 または215）ホイップしたクリームを $0 ， 1$ および 2 日 間冷蔵保存したときの結果である。この結果より変形抵抗 性の対数值之底面積は高い負の相関 $(r=-0.924, p<0.01)$
を示すことが分かった. 変形抵抗性は, 底面積と負の相関, すなわち「保形性」とは正の相関があると推察された。 よって, 本研究では変形抵抗性を保形性の指標値とした.

2. 冷蔵保存時のホイップドクリームの保形性変化

ホイップドクリームを $5{ }^{\circ} \mathrm{C} に て$ 保存した際の変形抵抗性 の変化を Fig. 2 に示した. ホイップ終了時の硬さによって 傾向が異なるが，ホイップ速度 $200 \mathrm{rpm}$ で調製したホイッ 
(a)

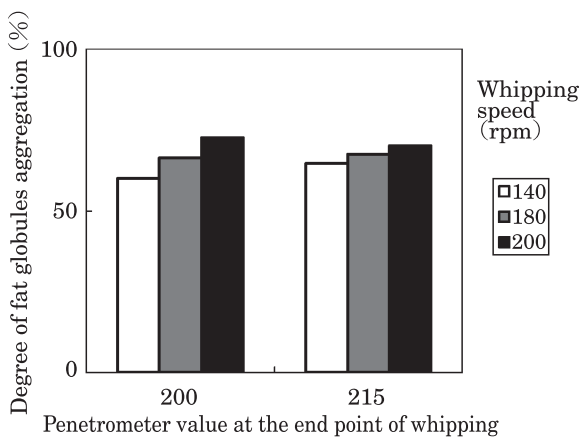

(C)

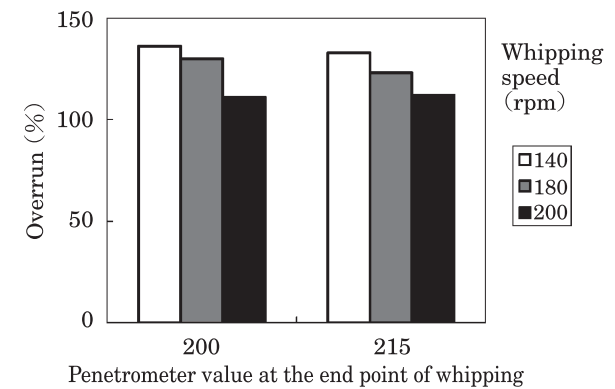

(b)

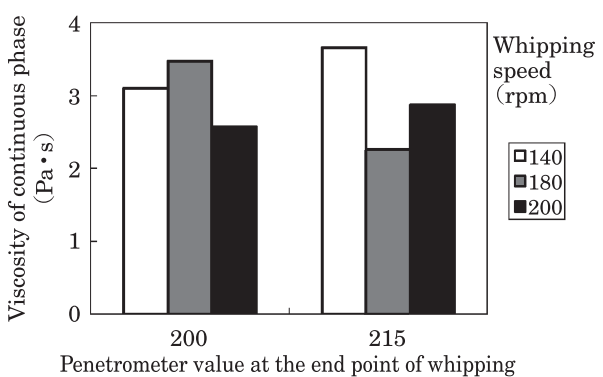

Fig. 3 Relation between the whipping speed and the each factor of whipped cream at the end point of whipping (a) Degree of fat globules aggregation, (b) continuous phase viscosity, (c) overrun.

プドクリームは保存中に変形抵抗性が低下しており，140 $\mathrm{rpm}$ 調製品は 3 条件の中では変形抵抗性が最も良く維持 されていた。前報)に扔いても $140 \mathrm{rpm}$ 調製品での貯蔵弾 性率の低下が最も少なく, $200 \mathrm{rpm}$ 調製品では顕著に低下 している現象が観察され，今回得られた結果は前報4)の傾 向と一致した。一方，前報)と同じ条件であるぺネトロ針 入度が 215 になる $180 \mathrm{rpm}$ 調製品は, 前報4) と同様 1 日保 存後で変形抵抗性が $140 \mathrm{rpm}$ 調製品より低下しているが, 前報)よりあ固めにホイップしたペネトロ針入度が 200 の 試料では, 変形抵抗性の変化傾向が $140 \mathrm{rpm}$ 調製品之ほぼ 同様であった，その原因について考察するため, 脂肪球凝 集と気泡の状態变化との関係を Fig. 3 に示した. 脂肪球凝 集率（Fig. 3 （a））およびオーバーラン（Fig. 3 (c)）は, ペネトロ針入度の違いの影響が見られなかった。一方, Fig. 3 （b）に示した連続相粘度は, ホイップ直後のペネト 口針入度により傾向が変わることが分かった。すなおち， $180 \mathrm{rpm}$ 調製品之 $200 \mathrm{rpm}$ 調製品之が同程度の保形性で あったペネトロ針入度 215 の試料では，両者の連続相粘度 あ同程度であった。また，180 rpm 調製品と $140 \mathrm{rpm}$ 調製 品とが同レベルの保形性であったペネトロ針入度 200 の試 験では, 両者の連続相粘度も同程度であった。これらの結 果から, ホイップ直後の連続相粘度は, 保存時の保形性に 影響を及ぼしていると推察された。

\section{3. 保存時の変形抵抗性に影響を与える因子の抽出}

前項の検討で連続相粘度が保存時の保形性に影響を及ぼ していることが示唆された。 また, 脂肪球凝集体は気泡と と屯に全体の構造を形成していると考えられ ${ }^{23)}$, 脂肪球凝 集体の状態抒よび気泡の存在状態は全体の力学物性に影響 を与えていると思われる。 そこで，保存中のホイップドク リームの变形抵抗性とオーバーラン，脂肪球凝集率との相 関をFig. 4 に示した. 2 つ実験結果をまとめて示した が，ホイップドクリームは保存するほど変形抵抗性が低下 し, 脂肪球凝集率ならびにオーバーランも低下した。よっ て, 図中の右上のデータはホイップ直後のあのであり, 左 下のデー夕は冷蔵保存期間が長いものである.

脂肪球凝集率は, 各ホイップ速度において変形抵抗性と 比較的高い相関を示しているが，ホイップ速度 $200 \mathrm{rpm}$ 調 製品では相関が低くなる傾向が見られた。オーバーラン は，ホイップ速度 $180 \mathrm{rpm}$ 調製品， $200 \mathrm{rpm}$ 調製品で変形 抵抗性之相関が高く, 脂肪球凝集率と变形抵抗性との相関 よりも高くなった。よって，ホイップ速度が小さいほど脂 肪球の凝集状態が変形抵抗性へ直接に影響を与え，ホイッ プ速度が大きいほどオーバーランが変形抵抗性へ直接に影 響を与えていると推察された。

Noda ら²)によるとホイップドクリームの連続相粘度は 全体の粘度より低く, 連続相粘度だけでは全体の力学物性 を説明しきれず，他の因子の影響も存在すると考察してい 
(a)
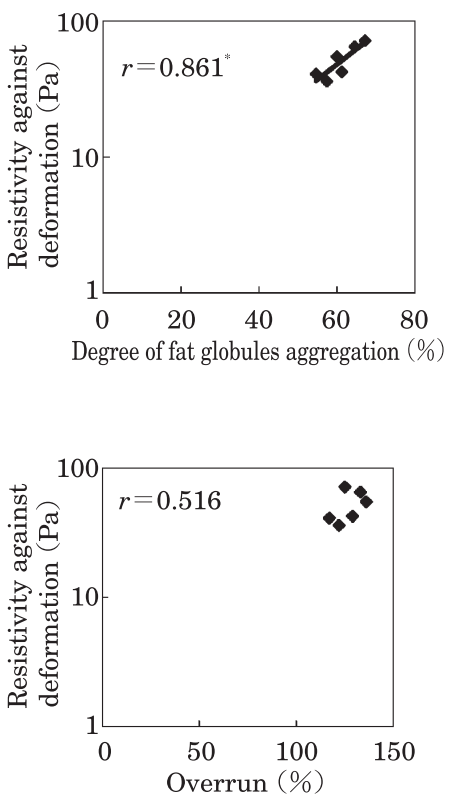

(b)
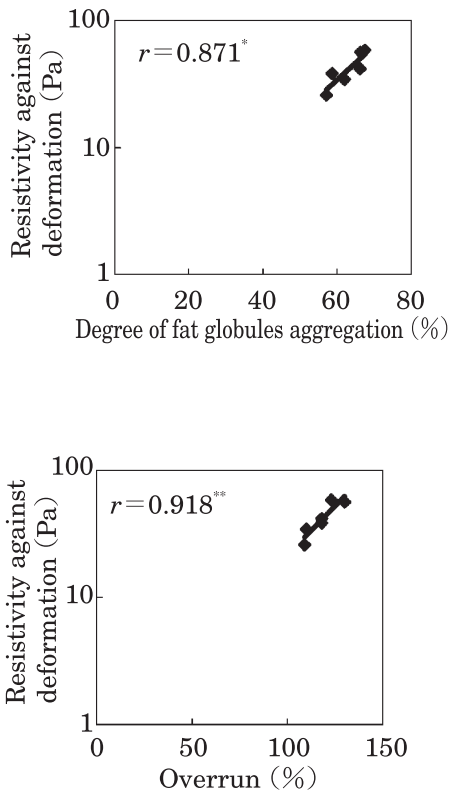

(C)
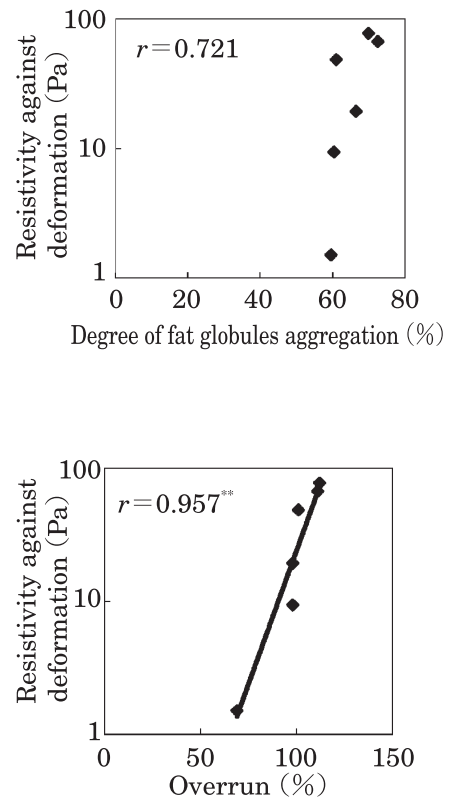

Fig. 4 Correlation among the resistivity against deformation, the degree of fat globules aggregation and the overrun Whipping speed : (a) $140 \mathrm{rpm}$, (b) $180 \mathrm{rpm}$, (c) $200 \mathrm{rpm}$.

*: Significant at $p<0.05,{ }^{* *}$ : significant at $p<0.01$.

(a)

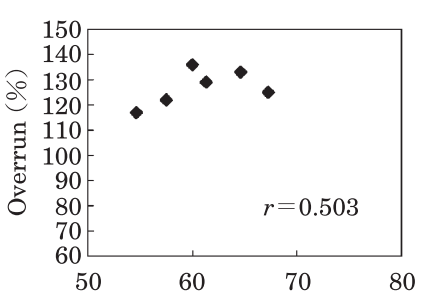

Degree of fat globules aggregation (\%) (b)

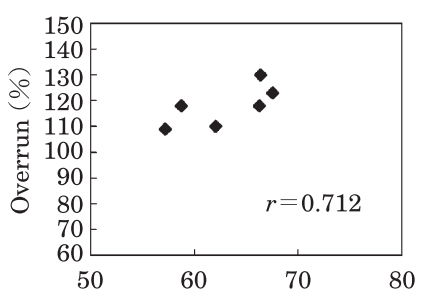

Degree of fat globules aggregation (\%) (c)
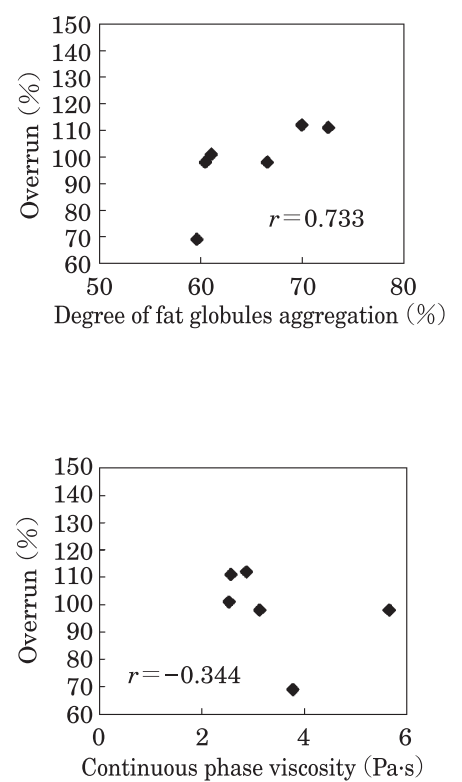
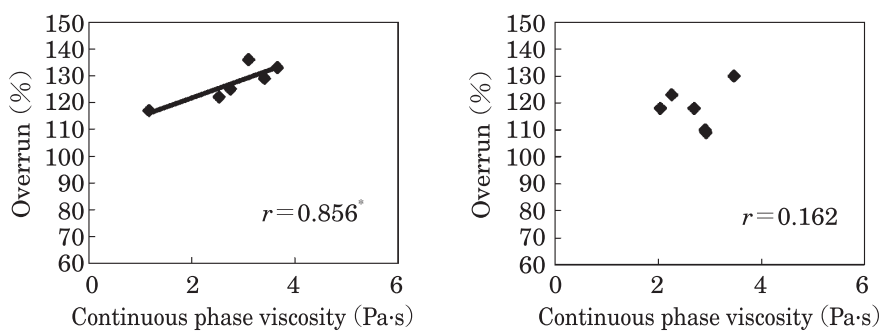

Fig. 5 Factors of fat globules aggregation for maintaining overrun

Whipping speed : (a) $140 \mathrm{rpm}$, (b) $180 \mathrm{rpm}$, (c) $200 \mathrm{rpm}$.

* : Significant at $p<0.05$.

る. 本結果からあ脂肪球凝集体と気泡の両方の因子が全体 の力学物性に影響を及ぼしていると推察され, 両方の因子 の挙動について解析した。

4. オーバーラン保持に影響を及ぼす脂肪球因子の抽出 前報4)では低速でホイップすると比較的しっかりとした
脂肪球ネットワークが形成され，反対に高速でホイップす ると脂肪球ネットワークは比較的不完全であると考察し た。 さらに, 低速ホイップ品では, 気泡径の変化が小さく, 逆に高速ホイップ品では気泡径の変化が大きいことを見出 した，また，脂肪球ネットワークは気泡を保持すると報告 
(a) Low-speed whipping (140 rpm)

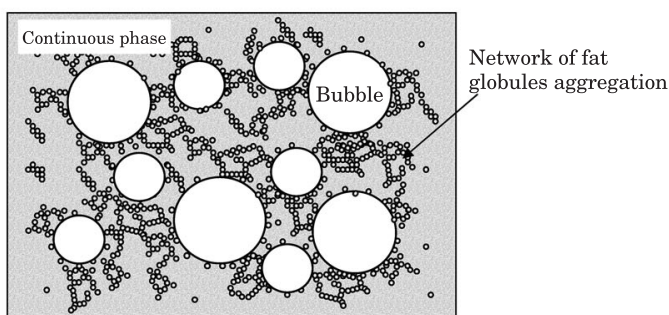
$\square\left[\begin{array}{l}\text { Bubbles disentraining followed by partial collapse } \\ \text { of fat globules network during refrigeration } \\ \text { (Stable bubble size) }\end{array}\right.$

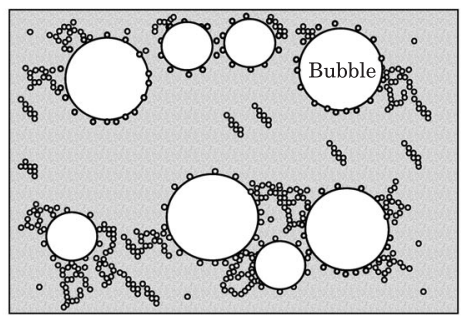

(b) High-speed whipping (200 rpm)
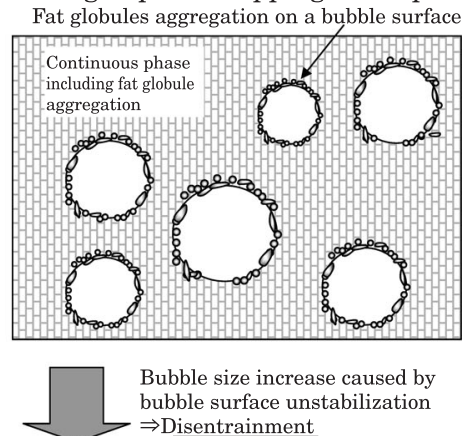
$\Rightarrow$ Disentrainment

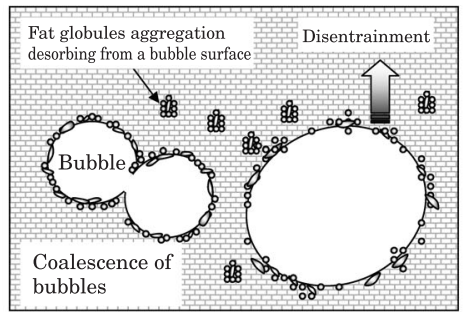

Fig. 6 Model for changing in the shape retention ability of whipped cream at different whipping speeds

(a)

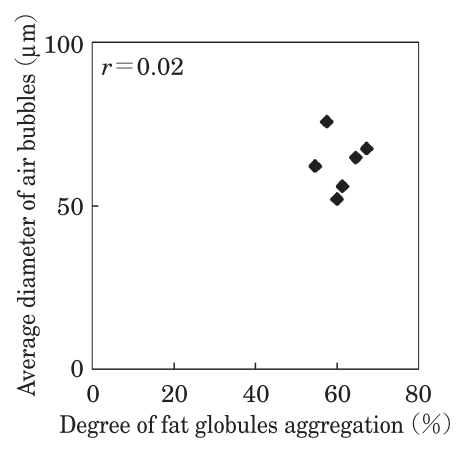

(b)

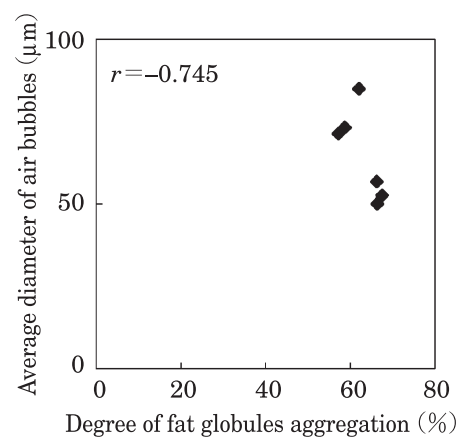

(c)

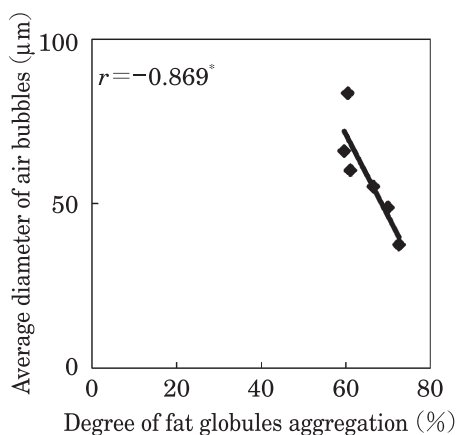

Fig. 7 Relation between the degree of fat globules aggregation and the diameter of bubbles

Whipping speed : (a) $140 \mathrm{rpm}$, (b) $180 \mathrm{rpm}$, (c) $200 \mathrm{rpm}$.

$*$ : Significant at $p<0.05$.

されている ${ }^{9)}$.このように気泡の保持は脂肪球凝集状態の 影響を受けていると考えられる。

そこで, 保存中のオーバーランと脂肪球凝集因子（脂肪 球凝集率，連続相粘度）との相関を Fig. 5 に示した. Fig. 5 は 2 つの実験のデー夕であるが，経時的にオーバーラン が低下したので，オーバーランが小さいものほど保存期間 が経過したときのデー夕となる。ホイップ速度 $140 \mathrm{rpm}$ 調 製品では連続相粘度とオーバーランとは高い正の相関が あった $(r=0.856, p<0.05)$.このことから, Fig. 6 に示し た保形性の変化機構のモデル (a) に示した通り, ホイップ 直後には連続相の脂肪球ネットワークにより気泡がホイッ プドクリーム内に保持され, 保存中のネットワーク崩壊に よって気泡がホイップドクリームの外に放出されやすくな ることが示唆された。一方, ホイップ速度 $180 \mathrm{rpm}$ 調製品
と $200 \mathrm{rpm}$ 調製品とでは, 脂肪球凝集率とオーバーランと の相関係数が高くなる傾向が見られた。また，連続相粘度 とオーバーランとの関係では, $140 \mathrm{rpm}$ 調製品で相関が見 られたが，180，200 rpm 調製品では相関が見られなかった ことより, 連続相の脂肪球疑集ネットワーク以外の因子む オーバーランの低下に寄与しているものと考えられた。

\section{5. 気泡径保持に影響を与える脂肪球凝集因子の抽出}

連続相に存在する脂肪球凝集ネットワーク以外でホイッ プドクリームのオーバーラン低下を引き起こす因子として は，気泡径の増加が考えられた。 そこで，保存中における ホイップドクリームの気泡径变化と脂肪球凝集率との相関 をFig. 7 に示した. Fig. 7 は 2 つの実験でのデータである が, 経時的に気泡径は増加したので, 気泡径が大きくなる ほど保存期間が経過したときのデータとなる。 ホイップ速 
(a)

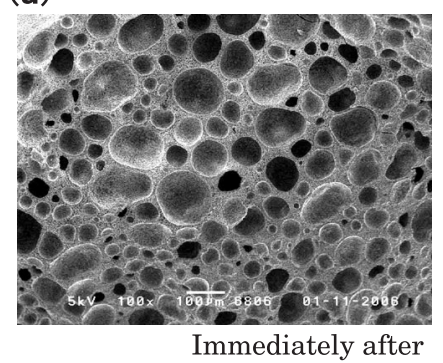

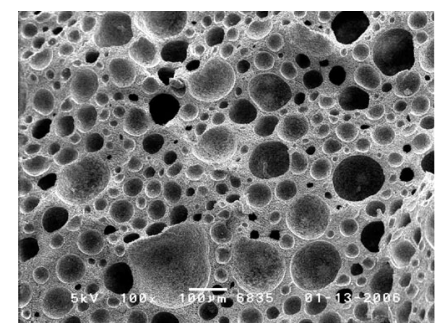

2 days after whipping

(b)

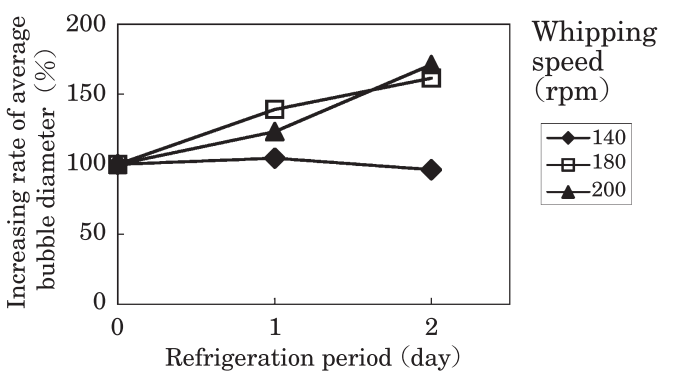

Fig. 8 Change in the increasing rate of average bubble diameter during refrigeration (a) SEM images of the creams prepared at 140rpm immediately after whipping or stored for 2 days, (b) increasing rate of average diameter of bubbles.

度 $140 \mathrm{rpm}$ 調製品では, 脂肪球凝集率と気泡径は無相関で あるが (Fig. 7 (a))，ホイップ速度が高速になるに従って相 関が高くなり， $200 \mathrm{rpm}$ 調製品では，有意な負の相関 $(r=$ $-0.869, p<0.05)$ が見られた (Fig. 7 (c))。すなおち，木 イップ速度 $200 \mathrm{rpm}$ 調製品では, 脂肪球凝集率が小さくな るにつれて気泡径が大きくなった，気泡径が大きくなると いうことは気泡が成長または合一するということであり， 気泡表面が不安定な状態であると推察される。 Fig. 8 に示 した気泡径変化率からもホイップ速度 $200 \mathrm{rpm}$ 調製品で は気泡径が経時的に大きくなっていることが見出された。

気泡表面には脂肪球が集まっており ${ }^{2)}$, 脂肪球およびそ の凝集体が気泡表面の表面張力を下げ，かつ力学的強度を 高めていると考えられた。 また，エマルションの界面にお いて，オボアルブミンのような立体構造の変化が少ない夕 ンパク質は界面弾性を増し， $\beta$-カゼインのような変形し やすい夕ンパク質で覆われた界面の界面弾性は低いことが 報告されている ${ }^{10)}$ ，気泡表面では変形しづらい小さな球状 粒子である脂肪球之, 立体的に比較的大きく変形可能であ る考えられる脂肪球凝集体で覆わ机ていると考えられる が，上記の知見から，大きな脂肪球凝集体で覆われた気泡 表面は表面弾性が低く, 表面被覆率も低いと推察される。 連続相粘度はホイップ速度 $140 \mathrm{rpm}$ 調製品では比較的低 くて 1.0 3.5 Pa.s であり, ホイップ速度 $200 \mathrm{rpm}$ 調製品 では比較的高くて 2.5 6.0 Pa.s であった (Fig. 5).このよ うに脂肪球凝集体が大きくなると連続相粘度が高くなるこ とが考えられ，ホイップ速度 $200 \mathrm{rpm}$ 調製品における気泡
表面は，表面レオロジ一的にも不安定であると推測され た。しかし，脂肪球または脂肪球凝集体自身は気泡表面を 保護して抢り，それらが表面から離脱しないと気泡の成 長・合一は生じにくいと考えられた。 Fig. 6 （b）に示した ように，ホイップ速度 $200 \mathrm{rpm}$ 調製品では，冷蔵保存中に 表面レオロジー的な不安定さが原因となって, 気泡表面に 存在している脂肪球凝集体が気泡表面から離脱しやすい状 態になると考えられた。それは，気泡径と脂肪球凝集率之 の相関が得られたことからも検証された（Fig. 7 (c))。一 方，デー夕を示さなかったが，連続相粘度と気泡径とは無 相関であったため, 脂肪球凝集体の離脱は無ホイップク リームの $90 \%$ 径 $(4 \mu \mathrm{m})$ 以下である比較的小さな脂肪球 凝集体が気泡表面から離脱する様式であると推察された。 一方, ホイップ速度 $140 \mathrm{rpm}$ 調製品では, 脂肪球凝集率と 気泡径との相関が見られなかった。Fig. 8 に示した保存中 の気泡径変化率加ら, 気泡径もホイップ速度 $140 \mathrm{rpm}$ 調製 品ではあまり変化していないため, 脂肪球凝集体は気泡表 面から離脱せず，表面を保護していると推察された。

\section{要約}

1. 保存時のホイップドクリームの変形抵抗性はホイッ プ速度が大きくなると低下，すなわち保形性が低下する傾 向が見られた。

2. ホイップ速度 $140 \mathrm{rpm}$ 調製品では, 脂肪球凝集率の 変化が変形抵抗性に与える影響が大きく, $200 \mathrm{rpm}$ 調製品 では, オーバーランの变化が変形抵抗性に大きく影響を与 
えると推察された。すなわち，ホイップドクリームの保形 性は, 脂肪凝集率とオーバーランの両方の影響を受けると 推察された。

3. ホイップ速度 $140 \mathrm{rpm}$ 調製品では, 連続相粘度が低 下するにつれてオーバーランが低下し， $200 \mathrm{rpm}$ 調製品で は, 脂肪球凝集率が低下寸るに従ってオーバーランが低下 する傾向であった。

4. ホイップ速度 $200 \mathrm{rpm}$ 調製品では, 脂肪球凝集率が 減少するに従って気泡径が増加した. 脂肪球凝集体が気泡 表面より離れ, 気泡表面が力学的に不安定な状態になるこ とにより気泡径が増加し, オーバーランの減少につながっ ている可能性があった. 一方, $140 \mathrm{rpm}$ 調製品では, 保存中 の気泡径の変化が小さく, 脂肪球凝集率と気泡径との相関 が無かったことより, 脂肪球凝集体は気泡表面から離脱す ることなく, 気泡表面が力学的に安定であると考えられた.

5. 脂肪球凝集体, 気泡がホイップドクリームの保形性 に与える影響に関するモデルを考察すると， $140 \mathrm{rpm}$ 調製 品の保形性変化は, 連続相中の脂肪球凝集ネットワークの 变化が原因であり，200 rpm 調製品の保形性变化は，気泡 表面からの脂肪球凝集体の離脱が原因であることが推察さ れた。

\section{文献}

1) Walstra, P., Wouters, J.T.M. and Geurts, T.J., Cream Products. In "Dairy Science and Technology" Second Edition (Taylor \& Francis) pp. 457 (2005).

2) Noda, M. and Shiinoki, Y., Microstructure and rheological behavior of whipping cream, J. Texture Stud., 17, 189-204 (1986).

3) Goff, H.D., Instability and Partial Coalescence of Whippable Dairy Emulsions, J. Dairy Sci., 80, 2620-2630 (1997).

4）井原啓一, 加治屋千鶴, 嶋田康伸, 浅野祐三, 小久保貞之, ホイップドクリーム物性に及ぼすホイップ速度の影響, 食 科工， 52，553-559 (2005).

5）高分子学会レオロジー委員会, ペネトロメーター, レオロ ジー測定法, 初版 (共立出版, 東京), pp. 129-130 (1965).

6）菊地基和，クリームの連続式ホイッピングに関する研究， 東北大学学位論文 (1992.10月).

7）小久保貞之, 桜井一美, 服部美穂, 冨田 守, アイスクリー ムの脂肪球凝集に及ぼすフリーザー出口温度とオーバーラ ンの影響, 日食工誌，41，347-354 (1994).

8）野田正幸, 山本晴敬，ホイップクリームの物性に及ぼす均 質処理の影響，食科工，43，896-903（1996）.

9) Darling, D.F., Recent advances in the destabilization of dairy emulsions, J. Dairy Res., 49, p. 695-712 (1982).

10) Rousseau, D., Fat crystals and emulsion stability - a review, Food Research International, 33, p. 3-14 (2000). (平成 18 年 6 月 8 日受付, 平成 19 年 1 月 18 日受理) 